OPEN ACCESS

Edited by:

Hao Chen,

Institute of Oceanology, Chinese Academy of Sciences (CAS), China

Reviewed by:

David C. Podgorski, University of New Orleans,

United States

Michael Thomas Montgomery, Texas A\&M University-Corpus Christi,

United States

*Correspondence:

Min Luo

mluo@shou.edu.cn

Duofu Chen

dfchen@shou.edu.cn

Specialty section:

This article was submitted to Deep-Sea Environments and Ecology, a section of the journal

Frontiers in Marine Science

Received: 18 October 2021 Accepted: 17 November 2021

Published: 02 December 2021

Citation:

Hu T, Luo M, Xu Y, Gong S and Chen D (2021) Production of Labile

Protein-Like Dissolved Organic Carbon Associated With Anaerobic Methane Oxidization in the Haima

Cold Seeps, South China Sea.

Front. Mar. Sci. 8:797084.

doi: 10.3389/fmars.2021.797084

\section{Production of Labile Protein-Like Dissolved Organic Carbon Associated With Anaerobic Methane Oxidization in the Haima Cold Seeps, South China Sea}

\author{
Tingcang $\mathrm{Hu}^{1}$, Min Luo ${ }^{1,2 *}$, Yunping $\mathrm{Xu}^{1}$, Shanggui Gong ${ }^{1}$ and Duofu Chen ${ }^{1 *}$ \\ 'Shanghai Engineering Research Center of Hadal Science and Technology, College of Marine Sciences, Shanghai Ocean \\ University, Shanghai, China, ${ }^{2}$ Laboratory for Marine Geology, Qingdao National Laboratory for Marine Science \\ and Technology, Qingdao, China
}

Cold seeps where methane-rich fluids escape from the seafloor generally support enormous biomass of chemosynthetic organisms and associated fauna. In addition to transporting a great amount of methane toward the seafloor, cold seeps also contribute to the aged, dissolved organic carbon (DOC) pool in the deep ocean. Here, two sediment cores from the "Haima cold seeps," northern South China Sea and a nearby reference core were analyzed for pore-water sulfate and DOC concentrations, $\delta^{13} \mathrm{C}$ of DOC, and optical properties of dissolved organic matter (DOM). High DOC concentrations $\left(0.9-3.7 \mathrm{mM}\right.$ ) accompanied by extremely low $\delta^{13} \mathrm{C}$ values ( -43.9 to $-76.2 \%$ ) suggest the conversion of methane into sedimentary DOC pool in the seep sediments. Parallel factor analysis (PARAFAC) of the fluorescence excitation-emission matrices shows higher fluorescent intensities of labile protein-like components (C2 and C4) and lower fluorescent intensities of refractory humic-like components (C1 and C3) in the seep cores compared to the reference core. The intensity of C2 is positively correlated with DOC concentrations and $\delta^{13} \mathrm{C}$-DOC in the seep sediments, suggesting that the labile protein-like DOM was produced by the anaerobic oxidation of methane (AOM). Moreover, low humification index (HIX) and high biological index (BIX) values also indicate intensified production of relatively labile DOM with lower degradation degree in the seep cores compared to the reference core. Hence, we highlight that methanederived DOC may serve as important carbon and energy sources for heterotrophic microbial communities due to its relatively labile nature.

Keywords: cold seeps, dissolved organic carbon, fluorescence spectrum, protein-like, AOM

\section{INTRODUCTION}

Dissolved organic carbon (DOC) in marine sediments represents an important by-product during the mineralization of particulate organic matter (POC; Aller, 1978; Berner, 1980; Komada et al., 2013; Burdige et al., 2016). Although the majority of POC is ultimately degraded to dissolved inorganic carbon (DIC), a varying fraction of POC is converted to DOC and accumulates in marine 
sediments (Burdige, 2002; Komada et al., 2013). This net production of DOC results in significantly higher pore water DOC concentrations than bottom seawater (Martin and McCorkle, 1993; Alperin et al., 1994; Burdige et al., 1999). DOC release from continental margin sediments can supply $\sim 180$ Tg $\mathrm{C}_{\text {year }}{ }^{-1}$ to the deep ocean, roughly equivalent to the riverine DOC input (Burdige et al., 1999), thereby affecting the characteristics of DOC in the deep ocean. Pore-water DOC in the very surface sediments is more labile and younger than the deep-ocean DOC due to rapid turnover of the labile POC component (Bauer et al., 1995; Komada et al., 2012). With the ongoing POC degradation in the sediments, increasingly amount of highly degraded, low-molecular-weight refractory DOC is produced and accumulated in the pore water. Based on numerical modeling results, Burdige et al. (2016) concluded that refractory DOC accounted for $>95 \%$ of the total pore-water DOC except that in the sediments close to the seafloor.

Marine sediments hold $\sim 500-10,000$ Gt carbon in the form of methane, predominantly occurred as gas hydrate (Kvenvolden, 1988; Buffet and Archer, 2004; Milkov, 2004). In the case of gas hydrate dissociation due to temperature and/or pressure changes, a large quantity of methane is released and transported toward the seafloor, forming cold seeps (Reeburgh, 2007). In addition to POC mineralization, DOC production in seepimpacted sediments is closely associated with the anaerobic oxidation of methane (AOM; Pohlman et al., 2011). As a result, significantly higher DOC concentrations have been observed in seep sediments compared to non-seep deep sea sediments (Hung et al., 2016; Amaral et al., 2021). Valentine et al. (2005) found that the proportion of methane-derived DOC increases with enhanced AOM rates and microbial activity in the cold seep sediments. Because of the influence of AOM, DOC is generally ${ }^{13} \mathrm{C}$ - and ${ }^{14} \mathrm{C}$-depleted in seep sediments. Mass-balance calculation using $\delta^{13} \mathrm{C}$ and $\Delta^{14} \mathrm{C}$ data showed that up to $86 \%$ of pore water DOC in the Arctic cold seep sediments was derived from fossil methane. Furthermore, Pohlman et al. (2011) suggested that methane-derived DOC accounted for up to $28 \%$ of DOC pool in the overlying bottom water, thereby likely representing an important but previously unconsidered source of pre-aged, ${ }^{13} \mathrm{C}$-depleted carbon into the deep ocean.

The potential impact of sediment-derived DOC on the deep ocean carbon cycle mainly depends on the reactivity of DOC. Optical property provides important insights into the source, composition, and reactivity of dissolved organic matter (DOM; Burdige et al., 2004; Coble, 2007; Dittmar and Stubbins, 2014; Chen et al., 2016; Wagner et al., 2020). Microbial metabolism sustained by deeply-sourced methane-rich fluids via mud volcanism has been documented to significantly contribute to the production of fluorescence dissolved organic matter (FDOM), $\sim 70 \%$ of which was characterized by labile, proteinlike fluorescence components (Amaral et al., 2021). Apart from the microbe-derived FDOM, thermogenically altered FDOM transported from the deep subsurface has also been detected in mud volcano pore fluids (Brogi et al., 2019). Moreover, bottom water collected from methane seeps contained more protein-like and lipid-like DOM components than non-seep areas, suggesting that cold seep sediments can be an important source of DOM to the bottom water, thereby impacting bottom-water DOM composition and reactivity (Sert et al., 2020).

Even though cold seep sediments have been recognized as an important source of overlying water DOM, knowledge on the reactivity of methane-derived DOM is quite limited, which hinders the assessment of the potential impact of methanederived, fossil DOC on the deep ocean DOC pool. Here, we analyzed pore-water concentrations of sulfate $\left(\mathrm{SO}_{4}{ }^{2-}\right)$ and DOC, stable carbon isotopic compositions $\left(\delta^{13} \mathrm{C}\right)$ of sedimentary DOC, and fluorescence properties of sedimentary DOM in the "Haima cold seeps," northern South China Sea (SCS). This work seeks to test the hypothesis that the majority of methane-derived DOC is relatively labile that could play an important role in sustaining heterotrophic metabolism in both the sediments and overlying bottom water.

\section{MATERIALS AND METHODS}

\section{Study Area}

The "Haima cold seeps" was discovered in the Qiongdongnan basin (QDNB), located in the extensional sector of the northern SCS passive margin, by the Guangzhou Marine Geological Survey in 2015. It consists of two active seep areas (ROV1 and ROV2; $7 \mathrm{~km}$ apart) with the water depth of $\sim 1,400 \mathrm{~m}$ (Figure 1). Geophysical imaging showed that the seeps were sustained by upward-migrating methane gas evidenced by the occurrence of gas chimney (Wang et al., 2008). Due to intense methane gas bubbling, methane hydrates were formed in shallow sediments, and living benthic fauna (e.g., tubeworms, clams, and mussels) were observed at the two seep sites by remotely operated vehicle (ROV) surveys (Liang et al., 2017).

\section{Sample Collection}

A gravity core (ROV1) and a push core (ROV5) were retrieved from the "Haima cold seeps" during the R/V Haiyang-6 cruise in September 2020. A reference core (QDN-C-S03) was collected from non-seep area using a gravity corer during R/V Haiyang10 cruise in August 2019. The recovered cores were immediately brought to the onboard laboratory and sliced into $2-20 \mathrm{~cm}$ intervals for pore water collection using Rhizon samplers. Aliquots for DOM analysis were stored in pre-combusted $\left(550^{\circ} \mathrm{C}\right.$ for $4 \mathrm{~h}$ ), $40 \mathrm{ml}$ brown glass bottle and frozen at $-20^{\circ} \mathrm{C}$ until further analysis. The aliquot for $\mathrm{SO}_{4}{ }^{2-}$ analysis was acidified with $\mathrm{HNO}_{3}$ and stored in a refrigerator $\left(\sim 4^{\circ} \mathrm{C}\right)$. After pore water extraction was completed, sediment samples were kept frozen at $-20^{\circ} \mathrm{C}$.

\section{Analytical Methods}

The concentrations of $\mathrm{SO}_{4}{ }^{2-}$ were determined using a Dionex ICS-900 ion chromatograph after a 500-fold dilution with Milli$\mathrm{Q}$ water. Ion Pac AS23-type column for anion and a mixed solution of $\mathrm{Na}_{2} \mathrm{CO}_{3}$ and $\mathrm{NaHCO}_{3}$ was used as eluent for $\mathrm{SO}_{4}{ }^{2-}$ concentration measurements. The analytical precision for $\mathrm{SO}_{4}{ }^{2-}$ is better than $2 \%$. DOC concentrations were determined by a high-temperature catalytic combustion method after a proper 
dilution with Milli-Q water using Shimadzu TOC-L analyzer with an analytical precision of $\pm 3 \%$. The deep seawater provided by Hansell laboratory (University of Miami) was used as the DOC standard validation. For $\delta^{13} \mathrm{C}$-DOC analyses, pore water samples were acidified to $\mathrm{pH} \sim 2$ with $6 \mathrm{M} \mathrm{HCl}$ for $72 \mathrm{~h}$ to remove inorganic carbon and then analyzed by high-temperature combustion on a Vario Cube TOC analyser connected to an Isoprime 100 continuous flow isotope ratio mass spectrometer. The analytical precision for $\delta^{13} \mathrm{C}$-DOC is better than $0.2 \%$.

Absorption spectra were scanned from 200 to $800 \mathrm{~nm}$ on an ultraviolet-visible (UV-Vis) spectrophotometer (Shimadzu Inc., Japan). Fluorescence excitation-emission matrices (EEMs) were measured using a Hitachi F-7000 luminescence spectrometer (Hitachi Inc., Japan). Excitation ranged 240-450 nm with $5 \mathrm{~nm}$ interval, while emission encompassed between 250 and $550 \mathrm{~nm}$ with $1 \mathrm{~nm}$ interval. The EEMs correction process included blank subtraction, inner filter correction and scatter removal. Fluorescence data were converted to Raman intensity units (RU) by normalizing the fluorescence collected in arbitrary units to the Raman peak area at $350 \mathrm{~nm}$. Subsequently, we used parallel factor analysis (PARAFAC) to determine the number of fluorescent components based on the split-half validation. The EEMs correction and PARAFAC modeling were performed using the MATLAB R2019a with the drEEM toolbox (Murphy et al., 2013). In addition, the optical indices, including the fluorescence index (FI), humification index (HIX) and biological index (BIX) were also analyzed. FI is a ratio of emission wavelengths at 470 and $520 \mathrm{~nm}$, gained at excitation $370 \mathrm{~nm}$, which is usually used to distinguish between autochthonous (microbial source) and allochthonous DOM (terrestrial source) (Mcknight et al., 2001; Cory et al., 2010). HIX is an area under the emission spectra 435$480 \mathrm{~nm}$ divided by the area $300-345 \mathrm{~nm}$, at excitation wavelength $254 \mathrm{~nm}$, which can be used to reflect the humic substance content and the degree of humification (Ohno, 2002). BIX is the ratio of emission intensity at $380 \mathrm{~nm}$ divided by $430 \mathrm{~nm}$ at excitation $310 \mathrm{~nm}$, which is positively correlated with the contribution of the autotrophic produced, low-degradation degree FDOM (Huguet et al., 2009).

\section{RESULTS}

\section{Downcore Profiles of $\mathrm{SO}_{4}{ }^{2-}$, Dissolved Organic Carbon, and $\delta^{13} \mathrm{C}-\mathrm{DOC}$}

The downcore variations in concentrations of $\mathrm{SO}_{4}{ }^{2-}$ and DOC and $\delta^{13} \mathrm{C}$-DOC values are shown in Figure 2. At the reference core (QDN-C-S03), the $\mathrm{SO}_{4}{ }^{2-}$ concentrations decrease slightly with depth from 26.0 to $22.4 \mathrm{mM}$. In contrast, the $\mathrm{SO}_{4}{ }^{2-}$ concentrations decline rapidly with depth at both seep cores, forming shallow sulfate-methane transition zone (SMTZ) $(\sim 120 \mathrm{~cm}$ for ROV1 and $\sim 30 \mathrm{~cm}$ for ROV5). Sedimentary DOC concentrations in all three cores $(0.31-3.7 \mathrm{mM})$ are significantly higher than the average deep-ocean DOC concentration $(\sim 40 \mu \mathrm{M})$ (Hansell and Carlson, 1998). The concentrations and $\delta^{13} \mathrm{C}$ values of DOC generally remain constant throughout the reference core, whereas both seep cores exhibit significantly higher DOC concentrations and lower $\delta^{13} \mathrm{C}$ values (Figure 2). In addition, the downcore profiles of DOC concentrations mirror that of $\delta^{13} \mathrm{C}$ values at both seep cores, with higher DOC concentrations corresponding to lower $\delta^{13} \mathrm{C}$ values and vice versa.

\section{Optical Properties of Sedimentary Dissolved Organic Matter}

Four fluorescent components $(\mathrm{C} 1-\mathrm{C} 4)$ were identified based on the EEM-PARAFAC model. These components were matched to previous models in the OpenFluor database that had a 0.95 minimum similarity score for the identical match between spectra. C1 (Ex/Em maxima: 250(320)/410 nm) and C3 (Ex/Em maxima: 255(370)/472) were matched to several PARAFAC models in the OpenFluor database and assigned as relatively refractory marine/microbial humic-like and terrestrial humiclike components (Coble, 1996; Murphy et al., 2014; Chen et al., 2016; Loginova et al., 2016; Figure 3). A number of labile protein-like components were matched to $\mathrm{C} 2(\mathrm{Ex} / \mathrm{Em}$ maxima: 275/350) in the OpenFluor database, indicating that $\mathrm{C} 2$ is a ubiquitous component of natural organic matter (Murphy et al., 2014). C4 (Ex/Em maxima: 265/285), also identified as a labile protein-like component, was matched to four studies focusing on seawater (Coble, 1996; Burdige et al., 2004; Murphy et al., 2014; Loginova et al., 2016). More specifically, C2 and C4 were thought to represent tryptophanlike and tyrosine-like compounds, respectively, in a variety of natural environments (Murphy et al., 2008; Chen et al., 2018). In addition, these labile protein-like components were also likely associated with aliphatic hydrocarbons (Dvorski et al., 2016; Podgorski et al., 2018; Mirnaghi et al., 2019). However, given the biogenic origin of methane in the "Haima" cold seeps (Wei et al., 2020), we presume a negligible contribution of petroleum-derived aliphatic compounds to the labile protein-like components. The fluorescence intensity of protein-like components (C2 + C4) account for $63 \% \pm 17 \%$ of the total FDOM intensity $(\mathrm{C} 1+\mathrm{C} 2+\mathrm{C} 3+\mathrm{C} 4)$ at the seep cores, which is significantly higher than those at the reference core $(17 \% \pm 8 \%)$. FI values (1.67-2.03) do not show significant differences between the seep cores and the reference core (Figure 4). In contrast, HIX values at the reference core $(0.84-0.92)$ are higher than those at the seep cores (0.47-0.71), while BIX values show an opposite pattern with slightly higher values at the seep cores than at the reference core.

\section{DISCUSSION}

\section{Sources of Dissolved Organic Carbon in the Seep Sediments}

Dissolved organic carbon in continental margin sediments is generally produced during the process of POC mineralization (Komada et al., 2013; Burdige et al., 2016). In the seep sediments, in addition to POC mineralization, DOC production is also associated with AOM process (Valentine et al., 2005; Pohlman et al., 2011). DOC concentrations at both seep cores (ROV1 and 


\section{A}

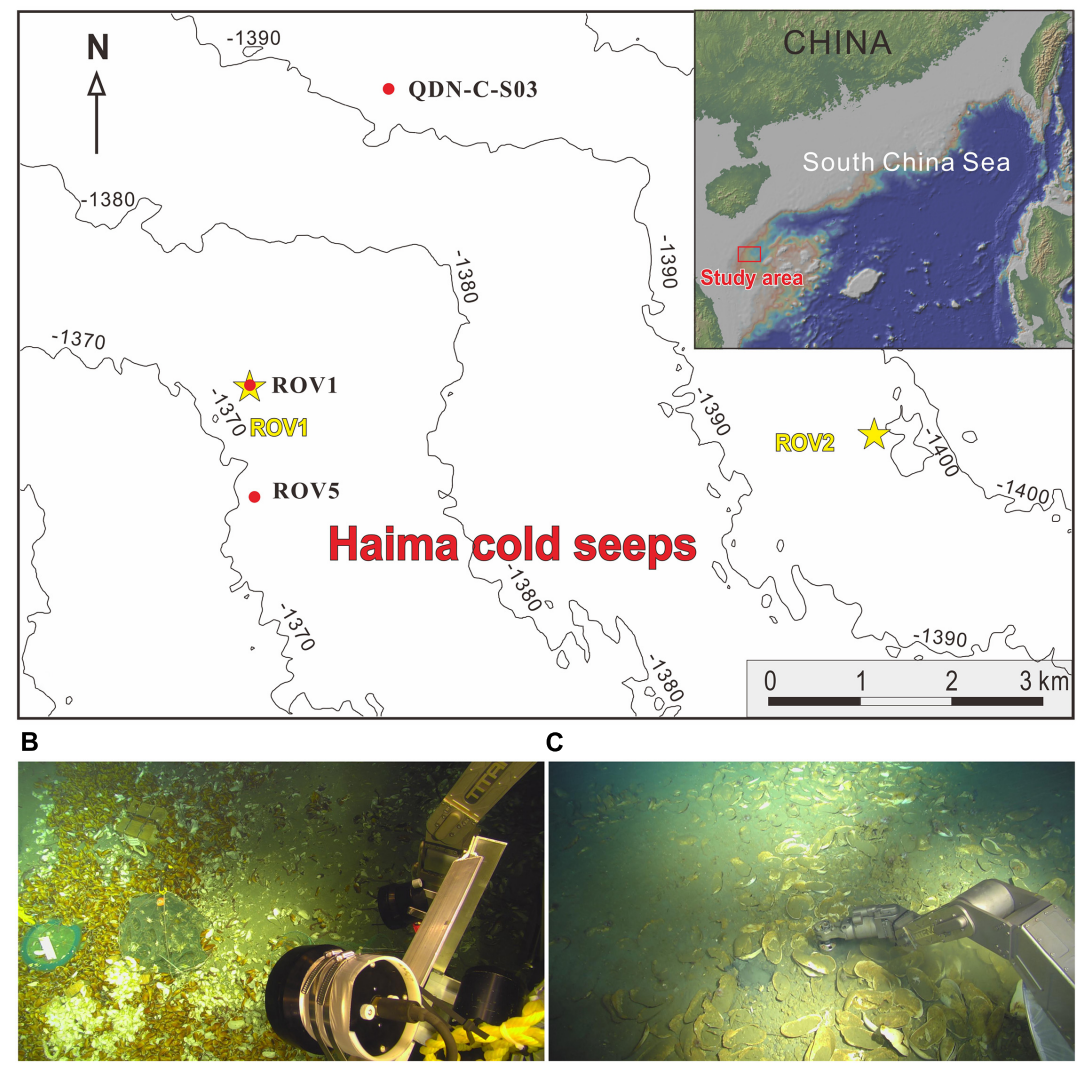

FIGURE 1 | (A) Locations of the three coring sites in the "Haima cold seeps" area. The yellow asterisks show the ROV1 and ROV2 seep areas. The red dots indicate the locations of coring sites. Cores ROV1 and ROV5 were taken from the active methane seep area and core QDN-C-S03 was collected from a non-seep area as a reference. Photos of seafloor where cores (B) ROV1 and (C) ROV5 were taken.

ROV5) are higher than those at the reference core (QDN-CS03), and ROV5 with shallower SMTZ exhibits higher average pore-water DOC compared to ROV1 with deeper SMTZ. These observations suggest that seep sediments contribute to DOC production with elevated methane flux and resulting AOM rate corresponding to enhanced DOC production. Moreover, ${ }^{13} \mathrm{C}$ depleted DOC measured at the seep cores $(-43.9$ to $-76.2 \%$ ) also points to a predominately methane-derived DOC as methane collected from "Haima cold seeps" is mostly biogenic in origin with $\delta^{13} \mathrm{C}$ values ranging between -72.3 and $-71.5 \%$ (Wei et al., 2020). In contrast, at the reference core absent of methane seepage, the $\delta^{13} \mathrm{C}$ values of DOC are significantly higher, exhibiting similar values of sedimentary TOC in the Qiongdongnan basin that receives both marine and terrestrial organic matter input (Cao et al., 2017). The slight decrease in $\mathrm{SO}_{4}{ }^{2-}$ at the reference core points to the dominance of particulate organic carbon sulfate reduction (POCSR) rather than $\mathrm{AOM}$ in consuming $\mathrm{SO}_{4}{ }^{2-}$, which is consistent with the inference of sedimentary TOC-derived DOC. Pore-water DOC production dominated by POCSR has also been observed in the anoxic sediments of the Arctic Ocean (Chen et al., 2016).

In addition, the significant inverse correlation between DOC concentrations and $\delta^{13} \mathrm{C}$-DOC values at both seep cores was observed (Figure 5), which was explained as the coupling between AOM and DOC production (Pohlman et al., 2011). The extremely low $\delta^{13} \mathrm{C}$-DOC values and high DOC concentrations at the SMTZ of both seep cores are associated with AOM. Meanwhile similar phenomenon also observed above the current SMTZ at ROV1 (Figure 2E). This shallower depth interval featuring DOC and $\delta^{13} \mathrm{C}$-DOC anomalies may represent the paleo-SMTZ where intense AOM and resulting DOC production was occurring when upward methane flux was higher compared to the current conditions. Fluctuation of SMTZ due to the variations in methane seepage intensities has been suggested to take place in the "Haima cold seeps" (Hu et al., 2019) and other seep areas worldwide (e.g., Borowski et al., 1999; Peketi et al., 2012; Sultan et al., 2016).

\section{Enhanced Production of Labile Dissolved Organic Carbon in the Seep Sediments}

The positive linear correlations were observed for DOC concentrations and total FDOM intensities (Figure 6), indicating the coupled production mechanisms of DOC and FDOM at the study cores. The y-intercepts are $0.26 \mathrm{mM}$ for QDN-C-S03, $0.39 \mathrm{mM}$ for ROV1 and $-0.70 \mathrm{mM}$ for ROV5, respectively, which represent the non-fluorescence fraction of DOM. Because 


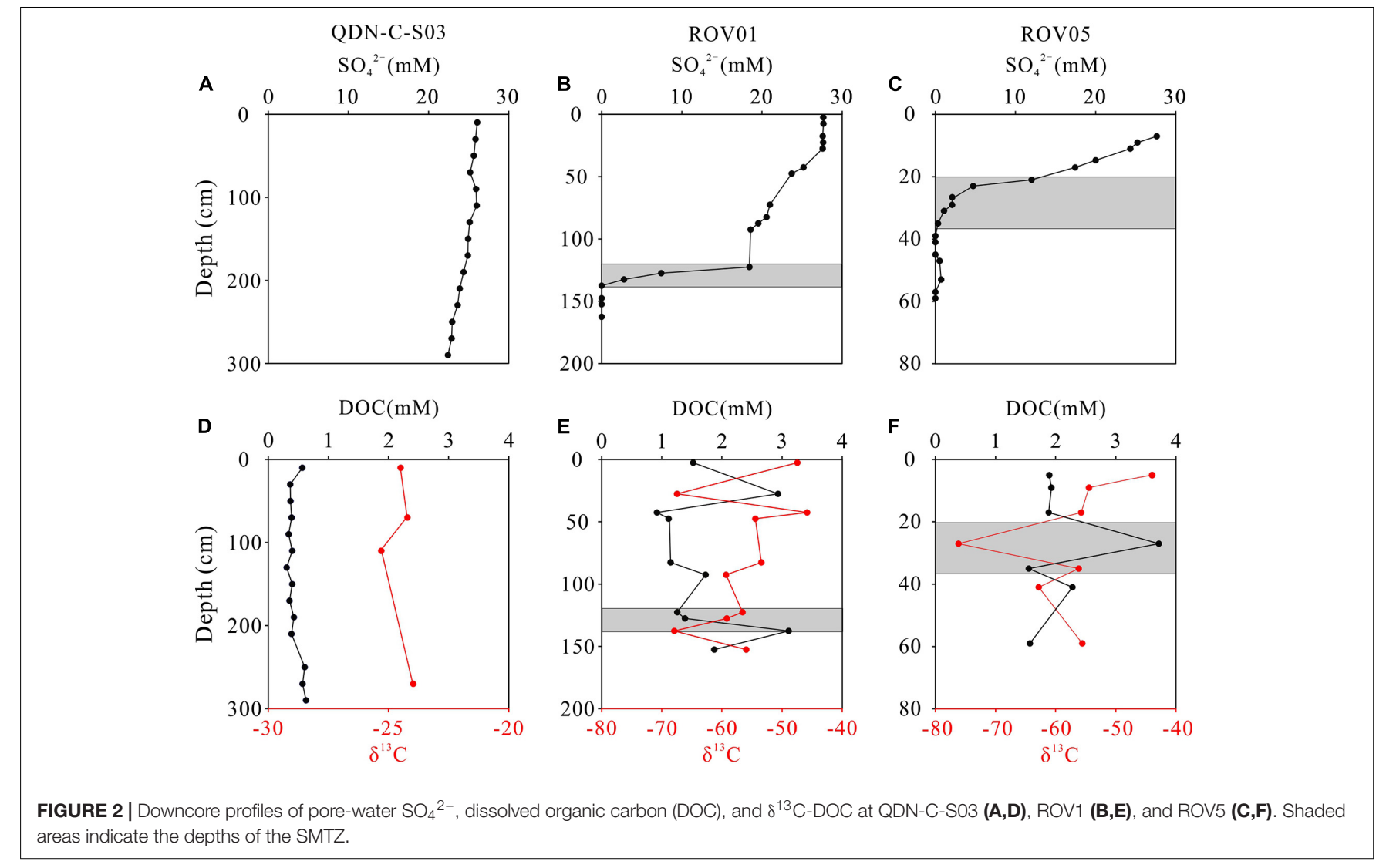

FGURE 2 Downcore profiles of pore-water $\mathrm{SO}_{4}{ }^{2-}$, dissolved organic carbon (DOC), and $\delta^{13} \mathrm{C}-\mathrm{DOC}$ at QDN-C-S03 (A,D), ROV1 (B,E), and ROV5 (C,F). Shaded
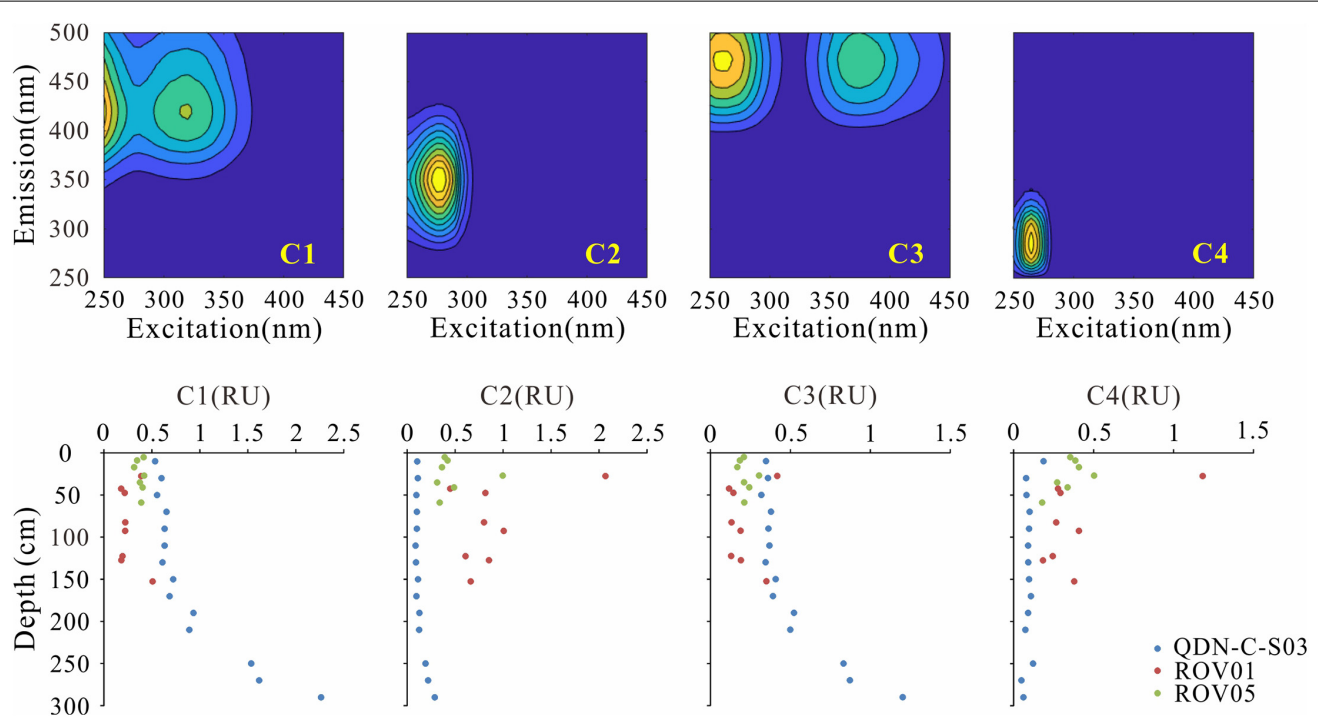

FIGURE 3 | Contour plots of the four components identified by EEM-PARAFAC (upper panel) and depth-profiles of the corresponding fluorescent intensities of fluorescence dissolved organic matter (FDOM) components (lower panel).

of the average DOC concentrations at QDN-C-S03 and ROV1 are 0.44 and $1.70 \mathrm{mM}$, we estimated that 41 and $77 \%$ of DOC pool are composed of fluorescence material at QDN-C-S03 and ROV1, respectively. The negative intercept value at ROV5 may imply a contribution of dissolved organic sulfur to FDOM pool.
Sulfurization of organic matter is a common process during early diagenesis stage through reaction of polysulfide and bisulfide on C-C double bonds and oxo-groups (Schouten et al., 1994; Werne et al., 2008; Raven et al., 2015). HS ${ }^{-}$produced by microbial sulfate reduction represents the major source for the 

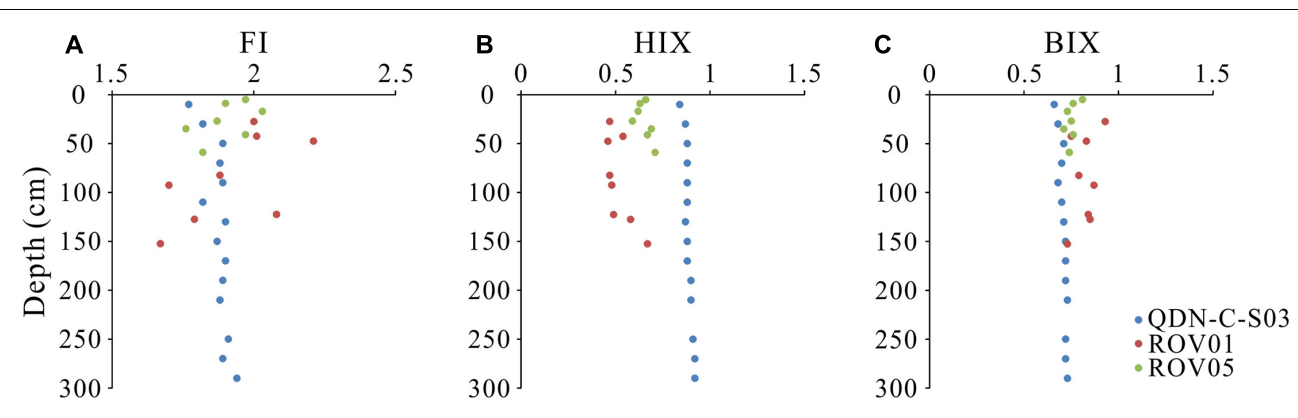

FIGURE 4 | Downcore variations in panel (A) fluorescence index (FI), (B) humification index (HIX), and (C) biological index (BIX) values at the seep cores (ROV1 and ROV5) and the reference core (QDN-C-SO3).
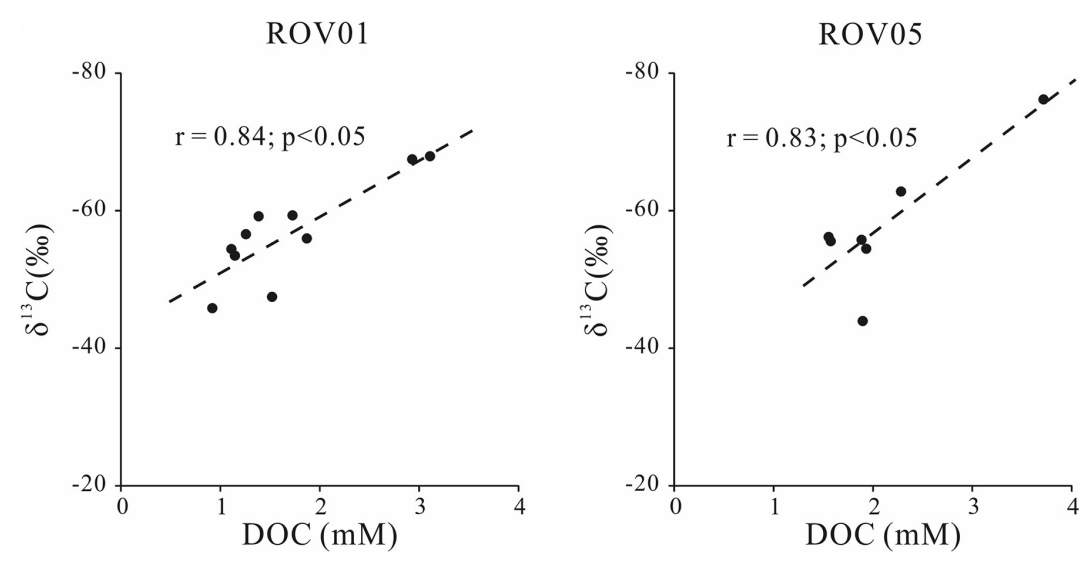

FIGURE 5 | Cross-plot of concentrations and $\delta^{13} \mathrm{C}$ of DOC at seeps sites (ROV1 and ROV5).

S-bearing organic compounds in anoxic sediments (Schmidt et al., 2009; Seidel et al., 2014; Sleighter et al., 2014). Also, the amount of S-bearing molecular formulas formed in the sediments is dependent upon the $\mathrm{HS}^{-}$concentrations in the pore water resulting from microbial sulfate reduction (Schmidt et al., 2017). Therefore, despite a lack of $\mathrm{HS}^{-}$data for both seep cores, the much higher AOM rates suggested by considerably shallower SMTZ at ROV5 than ROV1 likely explain a significant production of dissolved organic sulfur.

Although the exact formation mechanism of methane-derived DOC is currently unclear, biochemical processes including methane-sourced carbon incorporation into acetate or larger biomoleculars, microbial excretion, and biomass degradation have been proposed (Hoehler et al., 1994; Yang et al., 2020). Here, greater amount of fluorescent protein-like components (C2 and C4) and correspondingly less amount of humic-like components ( $\mathrm{C} 1$ and $\mathrm{C} 3$ ) at the seep cores (ROV1, ROV5) than those at the reference core (QDN-C-S03) suggests enhanced microbial activities and resulting release of more labile, proteinlike components at the seep cores (Figure 3). These results are consistent with the observation of significantly elevated microbial abundance in the seep sediments (Levin, 2005; Niu et al., 2017). Meanwhile, low HIX values, large fraction of protein-like components (46-80\%) and high BIX values also indicate intensified production of relatively labile FDOM with lower degradation degree associated with AOM at the seep cores compared to the reference core where sedimentary DOM is mostly produced by POCSR (Figure 4). Similar results have been reported at the mud volcanoes in the Gulf of Cádiz where the protein-like components accounted for $\sim 70 \%$ of the total FDOM (Amaral et al., 2021).

The positive correlations of $\mathrm{C} 2$ intensity with $\mathrm{DOC}$ concentrations and $\delta^{13} \mathrm{C}$-DOC at both seep cores (Figures 7, 8) also support our argument that labile protein-like DOM production is closely related to AOM. However, the correlation between the fluorescent intensity of the other protein-like component-C4 and DOC concentration as well as $\delta^{13} \mathrm{C}$-DOC at both seep cores is less remarkable compared to $\mathrm{C} 2$, likely implying complicated sources and formation mechanism of $\mathrm{C} 4$. Although the specific chemical composition of methane-derived DOC has yet to be investigated, it has been suggested that methane could be converted to low-molecular-weight, labile organic materials (e.g., acetate) by AOM (Yang et al., 2020). This inference was demonstrated by the identification of a complete archaeal acetogenesis pathway in the ANME-2a genome and the activity of the key enzymes in acetate generation (Yang et al., 2020). Notably, the acetate may account for a small fraction of the methane-derived labile DOC pool, which can subsequently sustain the highly divergent heterotrophic communities in the seep sediments (Valentine et al., 2005). 

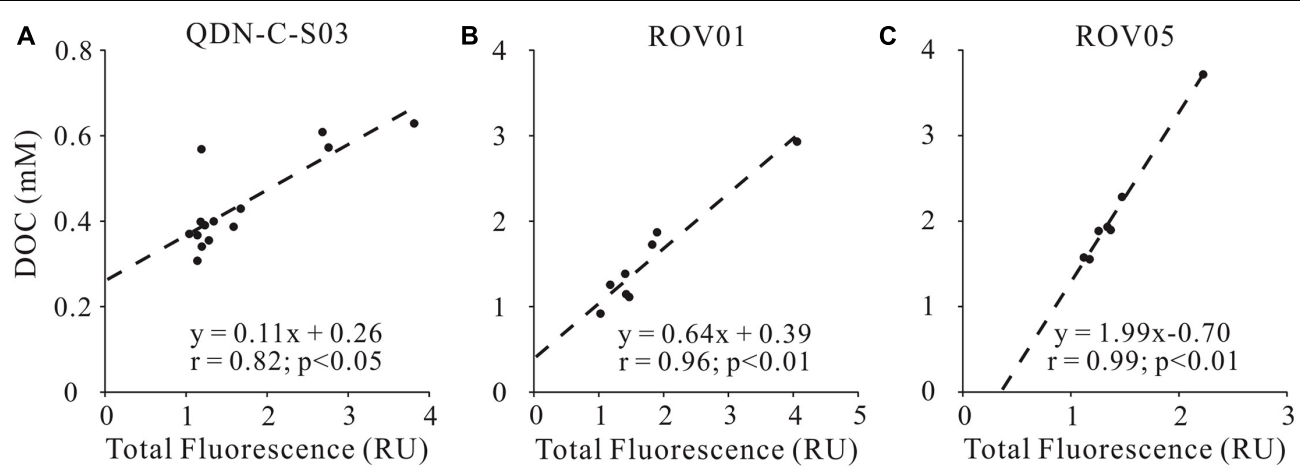

FIGURE 6 | Cross-plots of DOC concentrations and total fluorescence intensity at the sites ROV1 (A), ROV5 (B), and the QDN-C-S03 (C).
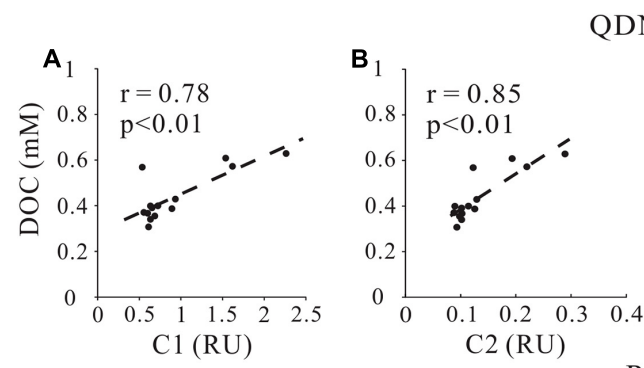

QDN-C-S03
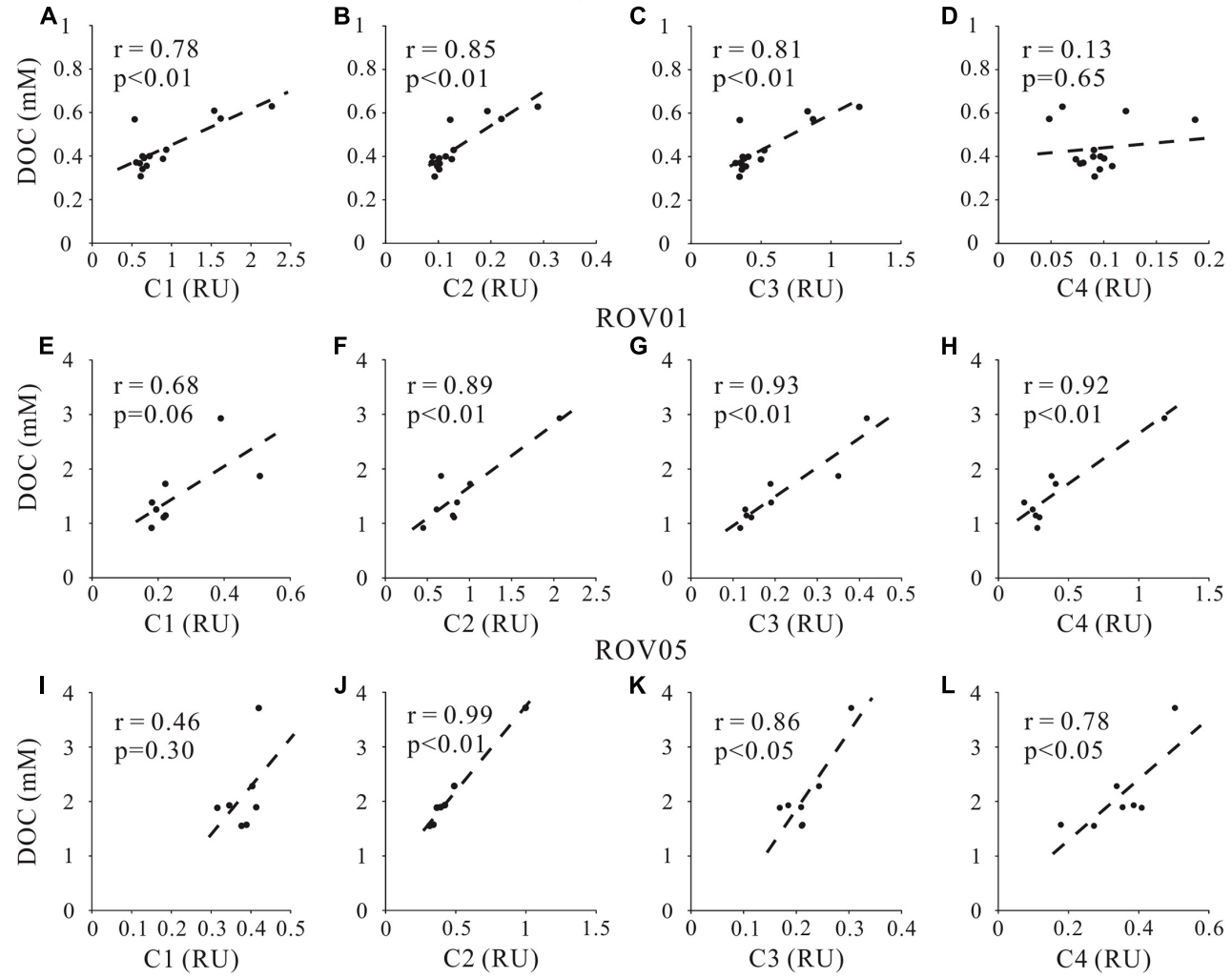

FIGURE 7 | Cross-plots of DOC concentrations and fluorescent intensity of FDOM components (C1, C2, C3, and C4) at cores QDN-C-S03 (A-D), ROV1 (E-H) and ROV5 (I-L).

In addition to producing protein-like components, $\mathrm{AOM}$ and accompanying microbial metabolism also produce humiclike refractory materials as shown by the positive correlations between humic-like component (C3) and DOC concentrations as well as $\delta^{13} \mathrm{C}$-DOC values at both seep cores (Figures 7,8 ). No significant correlations were found between marine/microbial humic-like $(\mathrm{C} 1)$ and DOC concentrations or $\delta^{13} \mathrm{C}$-DOC values (Figures 7, 8), indicating potential uncoupling of $\mathrm{C} 1$ production with $\mathrm{AOM}$ at seeps. However, the general positive correlations between $\mathrm{C} 1$ and DOC concentrations at the reference core may suggest a potential close relationship between $\mathrm{C} 1$ production and POC degradation (Figure 7). Indeed, higher $\mathrm{C} 1$ content at the reference core compared to the seep cores also suggests a greater contribution of POCSR at the reference core, likely reflecting inhibition of POCSR in the seep sediments (Niewohner et al., 1998; Figure 3). It is worth noting that the refractory property of the humic-like components in aquatic environments may not be necessarily associated with their chemical structures, but rather due to the environmental conditions such as their concentrations (Arrieta et al., 2015; Cerro-Gálvez et al., 2019a), 

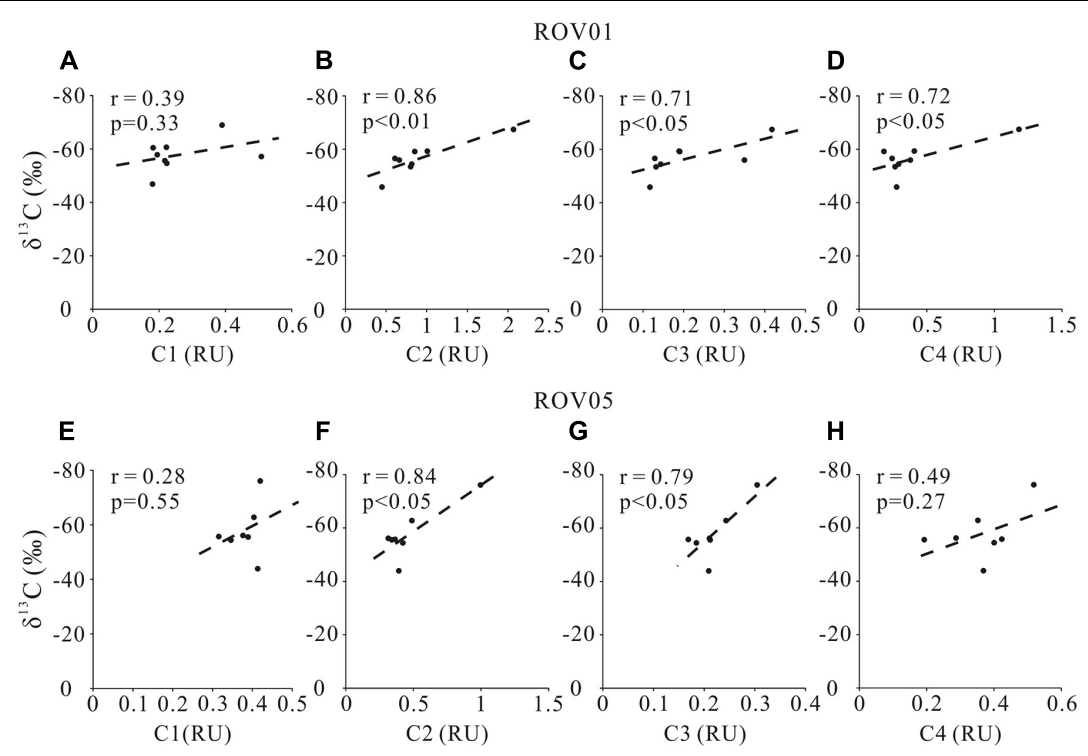

FIGURE 8 | Cross-plots $\delta^{13} \mathrm{C}-\mathrm{DOC}$ and FDOM components (C1, C2, C3, and C4) for the seeps sites ROV1 (A-D) and ROV5 (E-H).

nutrient availability (Cerro-Gálvez et al., 2019b), microbial ecology, enzyme function, and steric hindrance (i.e., matrix protection) (Kleber, 2010). Therefore, it may be possible that the humic-like component would change and become less refractory to microbial metabolism when they enter the ocean (Arrieta et al., 2015).

\section{Potential Impact of the Labile Dissolved Organic Carbon From Seep Sediments on the Deep Ocean Dissolved Organic Carbon Pool}

In general, the lability of DOC in the ocean is thought to vary with its ages, with younger, unaltered DOC being more easily utilized by aquatic heterotrophs than older, heavily modified one (Bauer et al., 1995; Raymond and Bauer, 2001; Raymond et al., 2007). However, Hood et al. (2009) found the glaciers runoff can supply a considerable amount of labile but aged DOC to marine ecosystems. Also, recent studies suggested that the reactivity of DOC is not directly related to its age, but mainly affected by its intrinsic chemical composition and extrinsic environments (Jiao et al., 2010; Wagner et al., 2020; Dittmar et al., 2021). Likewise, in the seep-impacted sediments, methane-derived DOC is extremely depleted in ${ }^{14} \mathrm{C}$ because methane is mostly produced by microbial or thermal degradation of pre-aged organic matter (Kuivila et al., 1990). Valentine et al. (2005) speculated that DOC in seep sediments contained labile compounds that could feed the heterotrophic microbial community. In this study, our optical analyses of sedimentary DOM demonstrate an enhanced production of relatively labile protein-like materials at both seep cores compared to the reference core, thereby supplying additional food sources and energy for heterotrophic prokaryotes in the seep sediments. Indeed, the observation of highly ${ }^{13} \mathrm{C}$-depleted lipid biomarkers in the seep carbonates likely suggested the uptake of AOM-derived OC by methaneoxidizing and sulfate-reducing consortia (Guan et al., 2019). In addition to supporting heterotrophic microbial activity in the seep sediments, DOC sourced from the seep sediments could also feed heterotrophy in the overlying seawater (Walker et al.,

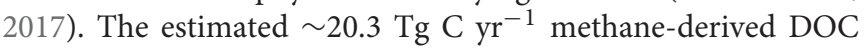
from seep sediments to the global ocean represents an important carbon and energy source for the heterotrophic communities in the deep ocean (Pohlman et al., 2011; Hung et al., 2016; Fu et al., 2020). Although the labile methane-derived DOC in the seep sediments is rapidly recycled, it could have a significant impact on the deep ocean DOC pool as aged and refractory DOC can also be produced during microbial metabolism.

Furthermore, in the geological past when major methane release from sediments due to gas hydrate dissociation, e.g., during the Palaeocene-Eocene Thermal Maximum (PETM), methane-derived DOC efflux could be substantially greater than the present-day condition (Zachos et al., 2005). As a result, a large amount of methane-derived DOC was subsequently converted to microbial biomass and buried in the sediments. We postulate that an enhanced production of labile protein-like DOC in the seep sediments may help explain the carbon isotopic excursion of sedimentary organic matter in the geological history and have implications in understanding the global DOC cycle.

\section{CONCLUSION}

Analyses and comparison of pore-water $\mathrm{SO}_{4}{ }^{2-}, \mathrm{DOC}$ concentrations and $\delta^{13} \mathrm{C}$ of $\mathrm{DOC}$ in the sediment cores taken from the "Haima cold seeps" regions (the northern SCS) suggest a significant contribution of methane-derived DOC at the seep cores. PARAFAC of the fluorescence excitation-emission matrices shows higher amount of protein-like fluorescent at the 
seep cores than the reference core. The enhanced production of relatively labile, protein-like fluorescent component is associated with $\mathrm{AOM}$, as also reflected by the extremely low $\delta^{13} \mathrm{C}$ of DOC. We highlight that the methane-derived DOC could serve as important carbon and energy sources for the heterotrophic communities and that it may contribute to explaining the $\delta^{13} \mathrm{C}$ excursion of sedimentary organic carbon in the geological history when major methane emission events took place.

\section{DATA AVAILABILITY STATEMENT}

The datasets presented in this study can be found in online repositories. The names of the repository/repositories and accession number(s) can be found below: https://doi.org/10. 6084/m9.figshare.16802116.

\section{AUTHOR CONTRIBUTIONS}

TH: investigation, sample collection, methodology, data analysis, and writing-original manuscript. ML: conceptualization,

\section{REFERENCES}

Aller, R. C. (1978). Experimental studies of changes produced by deposit feeders on porewater, sediment, and overlying water chemistry. Am. J. Sci. 278, 1185-1234. doi: 10.2475/ajs.278.9.1185

Alperin, M. J., Albert, D. B., and Martens, C. S. (1994). Seasonal variations in production and consumption rates of dissolved organic carbon in an organicrich coastal sediment. Geochim. Cosmochim. Acta 58, 4909-4929. doi: 10.1016/ 0016-7037(94)90221-6

Amaral, V., Romera-Castillo, C., and Forja, J. (2021). Submarine mud volcanoes as a source of chromophoric dissolved organic matter to the deep waters of the Gulf of Cádiz. Sci. Rep. 11:3200. doi: 10.1038/s41598-021-82 632-3

Arrieta, J. M., Mayol, E., Hansman, R. L., Herndl, G. J., Dittmar, T., and Duarte, C. M. (2015). Dilution limits dissolved organic carbon utilization in the deep ocean. Science 348, 331-333. doi: 10.1126/science.aac7249

Bauer, J. E., Reimers, C. E., Druffel, E. R. M., and Williams, P. M. (1995). Isotopic constraints on carbon exchange between deep ocean sediments and sea water. Nature 373, 686-689. doi: 10.1038/373686a0

Berner, R. A. (1980). Early Diagenesis: A Theoretical Approach. Princeton, NJ: Princeton University Press.

Borowski, W. S., Paull, C. K., and Ussler, W. (1999). Global and local variations of interstitial sulfate gradients in deep-water, continental margin sediments: sensitivity to underlying methane and gas hydrates. Mar. Geol. 159, 131-154. doi: 10.1016/S0025-3227(99)00004-3

Brogi, S. R., Kim, J. H., Ryu, J. S., Jin, Y. K., Lee, Y. K., and Hur, J. (2019). Exploring sediment porewater dissolved organic matter (DOM) in a mud volcano: clues of a thermogenic DOM source from fluorescence spectroscopy. Mar. Chem. 211, 15-24. doi: 10.1016/j.marchem.2019.03.009

Buffet, B., and Archer, D. (2004). Global inventory of methane clathrate: sensitivity to changes in the deep ocean. Earth Planet. Sci. Lett. 227, 185-199. doi: 10.1016/ j.epsl.2004.09.005

Burdige, D. J. (2002). "Sediment pore waters," in Biogeochemistry of Marine Dissolved Organic Matter, eds D. A. Hansell and C. A. Carlson (Cambridge, MA: Academic Press), 611-663.

Burdige, D. J., Berelson, W. M., Coale, K. H., McManus, J., and Johnson, K. S. (1999). Fluxes of dissolved organic carbon from California continental margin sediments. Geochim. Cosmochim. Acta 63, 1507-1515.

Burdige, D. J., Kline, S. W., and Chen, W. (2004). Fluorescent dissolved organic matter in marine sediment pore waters. Mar. Chem. 89, 289-311. doi: 10.1016/ j.marchem.2004.02.015 methodology, data analysis, funding acquisition, and writingreview and editing. YX: methodology and writing-review and editing. SG: sample collection and methodology. DC: conceptualization, writing-review and editing, and funding acquisition. All authors contributed to manuscript preparation.

\section{FUNDING}

This study was supported by the National Natural Science Foundation of China (Grants: 41730528 and 42176069), National Key R\&D Program of China (Grant: 2018YFC0310006), and Shanghai Rising-Star Program (21QA1403700).

\section{ACKNOWLEDGMENTS}

We thank the captains and crews of RVs Haiyang- 6 and Haiyang-10 for their invaluable help with coring process during the expeditions. We also thank Urban J. Wünsch for helpful discussion on DOM optical data.

Burdige, D. J., Komada, T., Magen, C., and Chanton, J. P. (2016). Modeling studies of dissolved organic matter cycling in Santa Barbara Basin (CA, USA) sediments. Geochim. Cosmochim. Acta. 195, 100-119.

Cao, M., Ma, Q., Wu, Y., and Zhang, J. (2017). Difference in organic matter distribution and degradation in surface sediment between Northern South China Sea and Hainan Island. Oceanol. Limnol. Sin. 48, 258-265.

Cerro-Gálvez, E., Casal, P., Lundin, D., Piña, B., Pinhassi, J., Dachs, J., et al. (2019a). Microbial responses to anthropogenic dissolved organic carbon in the Arctic and Antarctic coastal seawaters. Environ. Microbiol. 21, 1466-1481. doi: 10.1111/1462-2920.14580

Cerro-Gálvez, E., Sala, M. M., Marrasé, C., Gasol, J. M., Dachs, J., and Vila-Costa, M. (2019b). Modulation of microbial growth and enzymatic activities in the marine environment due to exposure to organic contaminants of emerging concern and hydrocarbons. Sci. Total Environ. 678, 486-498. doi: 10.1016/j. scitotenv.2019.04.361

Chen, M., Jung, J., Lee, Y. K., and Hur, J. (2018). Surface accumulation of low molecular weight dissolved organic matter in surface waters and horizontal offshelf spreading of nutrients and humic-like fluorescence in the Chukchi Sea of the Arctic Ocean. Sci. Total Environ. 639, 624-632. doi: 10.1016/j.scitotenv

Chen, M., Kim, J. H., Nam, S. I., Niessen, F., Hong, W. L., Kang, M. H., et al. (2016). Production of fluorescent dissolved organic matter in Arctic Ocean sediments. Sci. Rep. 6:39213. doi: 10.1038/srep39213

Coble, P. G. (1996). Characterisation of marine and terrestrial DOM in seawater using excitation-emission matrix spectroscopy. Mar. Chem. 51, 325-346. doi: 10.1016/0304-4203(95)00062-3

Coble, P. G. (2007). Marine optical biogeochemistry: the chemistry of ocean color. Chem. Rev 107, 402-418. doi: 10.1021/cr050350

Cory, R. M., Mcneill, K., Cotner, J. P., Amado, A., Purcell, J. M., and Marshall, A. G. (2010). Singlet oxygen in the coupled photochemical and biochemical oxidation of dissolved organic matter. Environ. Sci. Technol. 44, 3683-3689. doi: 10.1021/es902989y

Dittmar, T., and Stubbins, A. (2014). "Dissolved organic matter in aquatic systems," in Treatise on Geochemistry, 2nd Edn, eds H. D. Holland and K. K. Turekian (Amsterdam: Elsevier Ltd), 125-156.

Dittmar, T., Lennartz, S. T., Wises, H. B., Hansell, D. A., Santinelli, C., Vanni, C., et al. (2021). Enigmatic persistence of dissolved organic matter in the ocean. Nat. Rev. Earth Environ. 2, 570-583. doi: 10.1038/s43017-021-00183-7

Dvorski, S. E. M., Gonsior, M., Hertkorn, N., Uhl, J., Muller, H., Griebler, C., et al. (2016). Geochemistry of dissolved organic matter in a spatially highly resolved groundwater petroleum hydrocarbon plume cross-section. Environ. Sci. Technol. 50, 5536-5546. doi: 10.1021/acs.est.6b00849 
Fu, W., Qi, Y., Liu, Y., Wang, X., Druffel, E. R. M., Xu, X., et al. (2020). Production of ancient dissolved organic carbon in arctic ocean sediment: a pathway of carbon cycling in the extreme environment. Geophys. Res. Lett 47:e2020GL087119. doi: 10.1029/2020GL087119

Guan, H., Feng, D., Birgel, D., Peckmann, J., Roberts, H. H., Wu, N., et al. (2019). Lipid biomarker patterns reflect different formation environments of musseland tubeworm-dominated seep carbonates from the Gulf of Mexico (Atwater Valley and Green Canyon). Chem. Geol. 505, 36-47. doi: 10.1016/j.chemgeo. 2018.12.005

Hansell, D. A., and Carlson, C. A. (1998). Deep-ocean gradients in the concentration of dissolved organic carbon. Nature 395, 263-266. doi: 10.1038/ 26200

Hoehler, T. M., Alperin, M. J., Albert, D. B., and Martens, C. S. (1994). Field and laboratory studies of methane oxidation in an anoxic marine sediment-evidence for a methanogen-sulfate reducer consortium. Glob. Biogeochem. Cycles 8, 451-463. doi: 10.1029/94GB01800

Hood, E., Fellman, J., Spencer, R., Hernes, P. J., Edwards, R., Amore, D. D., et al. (2009). Glaciers as a source of ancient and labile organic matter to the marine environment. Nature 462, 1044-1047. doi: 10.1038/nature08580

Hu, Y., Luo, M., Liang, Q., Chen, L., Feng, D., Yang, S., et al. (2019). Pore fluid compositions and inferred fluid flow patterns at the Haima cold seeps of the South China Sea. Mar. Pet. Geol. 103, 29-40. doi: 10.1016/j.marpetgeo.2019.01. 007

Huguet, A., Vacher, L., Relexans, S., Saubusse, S., Froidefond, J. M., and Parlanti, E. (2009). Properties of fluorescent dissolved organic matter in the Gironde Estuary. Org. Geochem. 40, 706-719. doi: 10.1016/j.orggeochem.2009.03.002

Hung, C. W., Huang, K. H., Shih, Y. Y., Chen, H. H., Wang, C. C., Ho, C. Y., et al. (2016). Benthic fluxes of dissolved organic carbon from gas hydrate sediments in the northern South China Sea. Sci. Rep. 6:29597. doi: 10.1038/srep29597

Jiao, N., Herndl, G. J., Hansell, D. A., Benner, R., Kattner, G., Wilhelm, S. W., et al. (2010). Microbial production of recalcitrant dissolved organic matter: long-term carbon storage in the global ocean. Nat. Rev. Microbiol. 8, 593-599. doi: $10.1038 /$ nrmicro2386

Kleber, M. (2010). What is recalcitrant soil organic matter? Environ. Chem. 7, 320-332. doi: 10.1071/EN10006

Komada, T., Burdige, D. J., Crispo, S. M., Druffel, E. R. M., Griffin, S., Johnson, L., et al. (2013). Dissolved organic carbon dynamics in anaerobic sediments of the Santa Monica Basin. Geochim. Cosmochim. Acta 110, 253-273. doi: 10.1016/j. gca.2013.02.017

Komada, T., Polly, J. A., and Johnson, L. (2012). Transformations of carbon in anoxic marine sediments: implications from $\Delta^{14} \mathrm{C}$ and $\delta^{13} \mathrm{C}$ signatures. Limnol. Oceanogr. 57, 567-581. doi: 10.4319/lo.2012.57.2.0567

Kuivila, K. M., Murray, J. W., and De Vol, A. H. (1990). Methane production in the sulfate-depleted sediments of two marine basins. Geochim. Cosmochim. Acta 54, 403-411. doi: 10.1016/0016-7037(90)90329-J

Kvenvolden, K. A. (1988). Methane hydrate-a major reservoir of carbon in the shallow geosphere? Chem. Geol. 71, 41-51. doi: 10.1016/0009-2541(88)90104-0

Levin, L. A. (2005). Ecology of cold seep sediments: interactions of fauna with flow, chemistry and microbes. Oceanogr. Mar. Biol. 43, 1-46. doi: 10.1201/ 9781420037449-3

Liang, Q., Hu, Y., Feng, D., Chen, L., Yang, S., Liang, J., et al. (2017). Authigenic carbonates from newly discovered active cold seeps on the northwestern slope of the South China Sea: constraints on fluid sources, formation environments, and seepage dynamics. Deep Sea Res. Part 1 124, 31-41. doi: 10.1016/j.dsr.2017. 04.015

Loginova, A. N., Thomsen, S., and Engel, A. (2016). Chromophoric and fluorescent dissolved organic matter in and above the oxygen minimum zone off Peru. J. Geophys. Res. Oceans 121, 7973-7990.

Martin, W. R., and McCorkle, D. C. (1993). Dissolved organic carbon concentrations in marine pore waters determined by high-temperature oxidation. Limnol. Oceanogr. 38, 1464-1479. doi: 10.2307/2838277

Mcknight, D. M., Boyer, E. W., Westerhoff, P. K., Doran, P. T., Kulbe, T., and Andersen, D. T. (2001). Spectrofluorometric characterization of dissolved organic matter for indication of precursor organic material and aromaticity. Limnol. Oceanogr. 46, 38-48.

Milkov, A. V. (2004). Global estimates of hydrate-bound gas in marine sediments: how much is really out there? Earth Sci. Rev. 66, 183-197. doi: 10.1016/j. earscirev.2003.11.002
Mirnaghi, F. S., Pinchin, N. P., Yang, Z., Hollebone, B. P., Lambert, P., and Brown, C. E. (2019). Monitoring of polycyclic aromatic hydrocarbon contamination at four oil spill sites using fluorescence spectroscopy coupled with parallel factor-principal component analysis. Environ. Sci. Process. Impacts 21, 413-426. doi: 10.1039/C8EM00493E

Murphy, K. R., Stedmon, C. A., Graeber, D., and Bro, R. (2013). Fluorescence spectroscopy and multi-way techniques. PARAFAC Anal. Methods 5, 65576566. doi: 10.1039/C3AY41160E

Murphy, K. R., Stedmon, C. A., Waite, T. D., and Ruiz, G. M. (2008). Distinguishing between terrestrial and autochthonous organic matter sources in marine environments using fluorescence spectroscopy. Mar. Chem. 108, 40-58. doi: 10.1016/j.marchem.2007.10.003

Murphy, K. R., Stedmon, C. A., Wenig, P., and Bro, R. (2014). OpenFluor- an online spectral583 library of auto-fluorescence by organic compounds in the environment. Anal. Methods 6, 658-661. doi: 10.1039/c3ay41935e

Niewohner, C., Hensen, C., Kasten, S., Zabel, M., and Schulz, H. D. (1998). Deep sulfate reduction completely mediated by anaerobic methane oxidation in sediments of the upwelling area off Namibia. Geochim. Cosmochim. Acta 62:455e464. doi: 10.1016/S0016-7037(98)00055-6

Niu, M., Fan, X., Zhuang, G., Liang, Q., and Wang, F. (2017). Methanemetabolizing microbial communities in sediments of the Haima cold seep area, northwest slope of the South China Sea. FEMS Microbiol. Ecol 93:9. doi: 10. 1093/femsec/fix101

Ohno, T. (2002). Fluorescence inner-filtering correction for determining the humification index of dissolved organic matter. Environ. Sci. Technol. 36, 742-746.

Peketi, A., Mazumdar, A., Joshi, R. K., Patil, D. J., Srinivas, P. L., and Dayal, A. M. (2012). Tracing the paleo sulfate-methane transition zones and $\mathrm{H}_{2} \mathrm{~S}$ seepage events in marine sediments: an application of C-S-Mo systematics. Geochem. Geophys. Geosyst. 13:Q10007. doi: 10.1029/2012GC004288

Podgorski, D. C., Zito, P., McGuire, J. T., Martinovic-Weigelt, D., Cozzarelli, I. M., Bekins, B. A., et al. (2018). Examining natural attenuation and acute toxicity of petroleum-derived dissolved organic matter with optical spectroscopy. Environ. Sci. Technol. 52, 6157-6166. doi: 10.1021/acs.est.8b00016

Pohlman, J. W., Bauer, J. E., Waite, W. F., Osburn, C. L., and Chapman, N. R. (2011). Methane hydrate-bearing seeps as a source of aged dissolved organic carbon to the oceans. Nat. Geosci. 4, 37-41. doi: 10.1038/ngeo1016

Raven, M. R., Adkins, J. F., Werne, J. P., Lyons, T. W., and Sessions, A. L. (2015). Sulfur isotopic composition of individual organic compounds from Cariaco Basin sediments. Org. Geochem. 80, 53-59.

Raymond, P. A., and Bauer, J. E. (2001). Riverine export of aged terrestrial organic matter to the North Atlantic Ocean. Nature 409, 497-500. doi: 10.1038/ 35054034

Raymond, P. A., McClelland, J. W., Holmes, R. M., Zhulidov, A. V., Mull, K., Peterson, B. J., et al. (2007). Flux and age of dissolved organic carbon exported to the Arctic Ocean: a carbon isotopic study of the five largest arctic rivers. Global. Biogeochem. Cycles 21:GB4011. doi: 10.1029/2007GB002934

Reeburgh, W. S. (2007). Oceanic methane biogeochemistry. Chem. Rev. 107, 486-513. doi: 10.1021/cr050362v

Schmidt, F., Elvert, M., Koch, B. P., Witt, M., and Hinrichs, K.-U. (2009). Molecular characterization of dissolved organic matter in pore water of continental shelf sediments. Geochim. Cosmochim. Acta 73, 3337-3358. doi: 10.1016/j.gca.2009. 03.008

Schmidt, F., Koch, B. P., Goldhammer, T., Elvert, M., Witt, M., Lin, Y. S., et al. (2017). Unraveling signatures of biogeochemical processes and the depositional setting in the molecular composition of pore water DOM across different marine environments. Geochim. Cosmochim. Acta 207, 57-80. doi: 10.1016/j. gca.2017.03.005

Schouten, S., De Graaf, W., Sinninghe Damste, J. S., van Driel, G. B., and de Leeuw, J. W. (1994). Laboratory simulation of natural sulphurization: II. Reaction of multi-functionalized lipids with inorganic polysulphides at low temperatures. Org. Geochem. 22, 825-834. doi: 10.1016/0146-6380(94)90142-2

Seidel, M., Beck, M., Riedel, T., Waska, H., Suryaputra, I. G. N. A., Schnetger, B., et al. (2014). Biogeochemistry of dissolved organic matter in an anoxic intertidal creek bank. Geochim. Cosmochim. Acta 140, 418-434. doi: 10.1016/j.gca.2014. 05.038

Sert, M. F., D’Andrilli, J., Gründger, F., Niemann, H., Granskog, M. A., Pavlov, A. K., et al. (2020). Compositional differences in dissolved organic matter 
between arctic cold seeps versus non-seep sites at the svalbard continental margin and the Barents Sea. Front. Earth Sci. 8:552731. doi: 10.3389/feart.2020. 552731

Sleighter, R. L., Chin, Y.-P., Arnold, W. A., Hatcher, P. G., McCabe, A. J., McAdams, B. C., et al. (2014). Evidence of incorporation of Abiotic $S$ and $\mathrm{N}$ into prairie wetland dissolved organic matter. Environ. Sci. Technol. Lett. 1, 345-350. doi: 10.1021/ez500229b

Sultan, N., Garziglia, S., and Ruffine, L. (2016). New insights into the transport processes controlling the sulfate-methane-transition-zone near methane vents. Sci. Rep. 6:26701. doi: 10.1038/srep26701

Valentine, D. L., Kastner, M., Wardlaw, G. D., Wang, X., Purdy, A., and Bartlett, D. H. (2005). Biogeochemical investigations of marine methane seeps, Hydrate Ridge, Oregon. J. Geophys. Res. 110:GO2005. doi: 10.1029/2005JG000025

Wagner, S., Schubotz, F., Kaiser, K., Hallmann, C., Waska, H., Rossel, P. E., et al. (2020). Soothsaying DOM: a current perspective on the future of oceanic dissolved organic carbon. Front. Mar. Sci. 7:341. doi: 10.3389/fmars.2020.00341

Walker, B. D., Druffel, E., Kolasinski, J., Roberts, B. J., Xu, X., and Rosenheim, B. E. (2017). Stable and radiocarbon isotopic composition of dissolved organic matter in the Gulf of Mexico. Geophys. Res. Lett. 44, 8424-8434. doi: 10.1002/ 2017GL074155

Wang, X. J., Wu, S. G., Dong, D., Gong, Y. H., and Chai, C. (2008). Characteristics of gas chimney and its relationship to gas hydrate in Qiongdongnan Basin. Mar. Geol. Quat. Geol. 28, 103-108.

Wei, J., Li, J., Wu, T., Zhang, W., Li, J., Wang, J., et al. (2020). Geologically controlled intermittent gas eruption and its impact on bottom water temperature and chemosynthetic communities-a case study in the "HaiMa" cold seeps, South China Sea. Geol. J. 55, 6066-6078.
Werne, J. P., Lyons, T. W., Hollander, D. J., Schouten, S., Hopmans, E. C., and Sinninghe Damsteé, J. S. (2008). Investigating pathways of diagenetic organic matter sulfurization using compoundspecific sulfur isotope analysis. Geochim. Cosmochim. Acta 72, 3489-3502. doi: 10.1016/j.gca.2008.04.033

Yang, S., Lv, Y., Liu, X., Wang, Y., Fan, Q., Yang, Z., et al. (2020). Genomic and enzymatic evidence of acetogenesis by anaerobic methanotrophic archaea. Nat. Commun. 11:3941. doi: 10.1038/s41467-020-17860-8

Zachos, J. C., Röhl, U., Schellenberg, S. A., Sluijs, A., Hodell, D. A., Kelly, D. C., et al. (2005). Rapid acidification of the ocean during the paleocene-eocene thermal maximum. Science 308, 1611-1615. doi: 10.1126/science.1109004

Conflict of Interest: The authors declare that the research was conducted in the absence of any commercial or financial relationships that could be construed as a potential conflict of interest.

Publisher's Note: All claims expressed in this article are solely those of the authors and do not necessarily represent those of their affiliated organizations, or those of the publisher, the editors and the reviewers. Any product that may be evaluated in this article, or claim that may be made by its manufacturer, is not guaranteed or endorsed by the publisher.

Copyright (c) $2021 \mathrm{Hu}, \mathrm{Luo}, \mathrm{Xu}$, Gong and Chen. This is an open-access article distributed under the terms of the Creative Commons Attribution License (CC BY). The use, distribution or reproduction in other forums is permitted, provided the original author(s) and the copyright owner(s) are credited and that the original publication in this journal is cited, in accordance with accepted academic practice. No use, distribution or reproduction is permitted which does not comply with these terms. 